MaPan : Jurnal Matematika dan Pembelajaran

p-ISSN: 2354-6883 ; e-ISSN: 2581-172X

Volume 5, Nomor 1, Juni 2017

\title{
PENGARUH GAYA BELAJAR MENGAJAR MAHASISWA DAN DOSEN TERHADAP HASIL BELAJAR MAHASISWA JURUSAN PENDIDIKAN MATEMATIKA FAKULTAS TARBIYAH DAN KEGURUAN UIN ALAUDDIN MAKASSAR
}

\author{
Nurkhalisah Latuconsina1), Baharuddin ${ }^{2)}$ \\ 1,2Fakultas Tarbiyah dan Keguruan UIN Alauddin Makassar \\ 1,2Kampus II: Jalan H. M. Yasin Limpo Nomor 36 Samata-Gowa \\ E-mail: nurkhalisaltc99@gmail.com ${ }^{1}$, , erick_tosin@yahoo.co.id ${ }^{2)}$
}

\begin{abstract}
Abstrak
Penelitian ini bertujuan untuk mengetahui pengaruh gaya belajar mahasiswa dan gaya mengajar dosen terhadap hasil belajar mahasiswa Jurusan Pendidikan Matematika Fakultas Tarbiyah dan Keguruan UIN Alauddin Makassar. Jenis penelitian ini adalah penelitian ex post facto, dengan pengumpulan data menggunakan angket, observasi, dan dokumentasi, dengan jumlah responden sebesar 37 responden, teknik analisis data yang digunakan yaitu analisis data deskriptif, dengan uji $\mathrm{t}$ dan F. Dari hasil analisis data kuantitatif, uji $\mathrm{t}$ dan $\mathrm{F}$, maka dapat disimpulkan bahwa: (1) ada pengaruh yang positif dan signifikan antara gaya belajar terhadap hasil belajar mahasiswa dengan hasil $t_{\text {hitung }}$ $>t_{\text {tabel }}(0,735>0,05),(2)$ ada pengaruh yang positif dan signifikan antara Gaya Mengajar terhadap hasil belajar mahasiswa dengan hasil thitung $>$ $t_{\text {tabel }}(0,538>0,05),(3)$ ada pengaruh gaya belajar dan mengajar secara simultan terhadap hasil belajar mahasiswa.
\end{abstract}

Kata Kunci: Gaya Belajar, Gaya Mengajar, Hasil Belajar

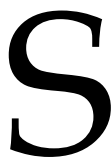

etiap mahasiswa memiliki cara belajar yang berbeda-beda. Beberapa mahasiswa mungkin akan lebih mudah mengingat apasaja yang ia baca, sedang mahasiswa yang lain mungkin lebih mudah mengingat apa yang ia dengar. Gaya belajar merupakan cara menerima informasi dari dunia sekelilingnya. Gaya belajarlah yang merupakan faktor yang mempercepat proses belajar mahasiswa kita. Pada dasarnya ada empat gaya belajar, yakni visual, auditori, dan kinestetis. Gaya visual mengandalkan penglihatan pada apapun yang ditangkap mata, gaya auditori mengandalkan pendengaran dan pembicaraan. Sedangkan gaya kinestetis mengandalkan sisimotorik. Setiap mahasiswa memiliki kelebihan, memiliki cara belajar yang berbeda ini disebut superlink. Bila mahasiswa belajar dengan memperhatikan superlinknya, maka belajar akan terasa mudah, tidak loyo, dan otomatis paham materi yang disajikan oleh dosennya. Penelitian ini dikatakan penting karena dalam faktanya, banyak mahasiswa mengalami kebingungan dalam menerima 
materi kuliah karena tidak mampu mencerna materi yang diberikan oleh dosen. Juga untuk menghilangkan mitos tentang matakuliah yang sulit dan mahasiwa yang diberi lebel bodoh ataupun lebel-lebel lainnya, serta untuk mengetahui seberapa besar pengaruh gaya mengajar dosen dan gaya belajar mahasiswa terhadap hasil belajar yang diperoleh mahasiswa selama proses perkuliahan berlangsung, khususnya mahasiswa jurusan matematika fakultas tarbiyah dan keguruan.

Berdasarkan latar belakang di atas maka penulis tertarik meneliti tentang pengaruh gaya mengajar dosen dan gaya belajar mahasiswa terhadap hasil belajar mahasiswa terutama mahasiswa Jurusan Matematika Fakultas Tarbiayah UIN Alauddin Makassar. Selain itu, penelitian ini juga bertujuan mengetahui pengaruh gaya belajar mahasiswa dan gaya mengajar dosen terhadap hasil belajar mahasiswa Jurusan Pendidikan Matematika Fakultas Tarbiyah dan Keguruan UIN Alauddin Makassar

\section{GAYA BELAJAR MAHASISWA}

Menurut De Porter dan Hernacki, gaya belajar adalah kombinasi dari menyerap, mengatur, danmengolahinformasi. Terdapat tiga jenis gaya belajar berdasarkan modalitas yang digunakan individu dalam memproses informasi (perceptual modality).

a. Visual (Visual Learners), menitik beratkan pada ketajaman penglihatan.

b. Auditori (Auditory Learners), mengandalkan pada pendengaran untuk bisa memahami dan mengingatnya.

c. Kinestetik (Kinesthetic Learners), mengharuskan individu yang bersangkutan menyentuh sesuatu yang memberikan informasi tertentu agar ia bisa mengingatnya.

\section{GAYA MENGAJAR DOSEN}

Gaya mengajar adalah bentuk penampilan dosen saat proses belajar mengajar baik yang bersifat kurikuler maupun psikologis.

Ada empat Gaya pembelajaran Dosen yang muncul di saat mengajar yaitu:

a. Dosen elementary, lebih memberikan understanding, comprehension dan memorizing pada mahasiswa.

b. Dosen intermediate, menekankan pada critical thinking and doing.

c. Dosen advanced, dengan ciri ini menekankan pada problem solving, why, analysis, synthesis and idea. 
d. Dosen creative, mengajak mahasiswa untuk thinking out of the box. Mengevaluasi, innovation, kasus, diskusi, penelitian, proyek, karya ilmiah, jurnal dan seminar.

\section{HASIL BELAJAR}

Hasil belajar dapat dijelaskan dengan memahami dua kata yang membentuknya, yaitu "hasil" dan "belajar". Pengertian hasil (product) menunjuk pada suatu perolehan akibat dilakukannya suatu aktivitas atau proses yang mengakibatkan berubahnya input secara fungsional.

Belajar merupakan faktor yang luas dibentuk oleh pertumbuhan, perkembangan tingkahlaku. Menurut Skinner, belajar adalah perilaku pada saat orang belajar dengan memberikan respon lebih baik yaitu kesempatan terjadinya peristiwa yang menimbulkan respons pembelajar, response pembelajar, dan konsekuensi yang bersifat menguatkan respons tersebut. Jadi, hasil belajar adalah perubahan yang diperoleh anak setelah melalui kegiatan belajar.

\section{METODE PENELITIAN}

Jenis penelitian yang digunakan adalah penelitian ex post facto. penelitian yang dilakukan sesudah perbedaan-perbedaan dalam variabel bebas terjadi karena perkembangan kejadian secara alami. Jadi, penelitian ex post facto merupakan penelitian dimana telah terjadi perlakuan pada variabel bebasnya atau perlakuannya tidak dilakukan pada saat penelitian berlangsung.Penelitian ini menggunakan data penelitian berupa angka-angka dan analisis menggunakan statistik. Populasi dalam penelitian ini adalah seluruh mahasiswa jurusan Matematika angkatan 2013 fakultas tarbiyah dan keguruan UIN Alauddin Makassar, yang terdiridari 110 mahasiswa dan yang menjadi sampel penelitian ini yang berjumlah 37 mahasiswa. Instrument dari penelitian ini yaitu: lembar observasi chek-list dan angket.

\section{HASIL PENELITIAN DAN PEMBAHASAN}

\section{Uji Validitas}

Tabel 1. Output SPSS Gaya Belajar

KMO and Bartlett's Test

\begin{tabular}{|llr|}
\hline Kaiser-Meyer-Olkin Measure of Sampling Adequacy. & 502 \\
Bartlett's Test of & Approx. Chi-Square & 423,893 \\
Sphericity & df & 136 \\
& Sig. & 000 \\
\hline
\end{tabular}

34 | Volume 5, Nomor 1, Juni 2017 
Tabel 2. Output SPSS Gaya Mengajar

KMO and Bartlett's Test

\begin{tabular}{|ll|r|}
\hline Kaiser-Meyer-Olkin Measure of Sampling Adequacy. & 604 \\
Bartlett's Test of & Approx. Chi-Square & 1966,684 \\
Sphericity & df & 903 \\
& Sig. & 000 \\
\hline
\end{tabular}

\section{Uji Reliabilitas}

Tabel 3. Estimasi Koefisien Reliabilitas Gaya Belajar

Reliability Statistics

\begin{tabular}{|r|r|}
\hline \multicolumn{1}{|c|}{$\begin{array}{c}\text { Cronbach's } \\
\text { Alpha }\end{array}$} & N of Items \\
\hline, 728 & 17 \\
\hline
\end{tabular}

Tabel 4. Estimasi Koefisien Reliabilitas Gaya Belajar

Reliability Statistics

\begin{tabular}{|r|r|}
\hline $\begin{array}{c}\text { Cronbach's } \\
\text { Alpha }\end{array}$ & N of Items \\
\hline .882 & 43 \\
\hline
\end{tabular}

\section{Analisis Deskriptif}

a. Gaya Belajar

Tabel 5. Tabel Gaya Belajar Visual, Auditori, Dan Kinestetik

\begin{tabular}{lcccr}
\hline \multirow{2}{*}{ Deskriptif } & \multicolumn{4}{c}{ Gaya Belajar } \\
\cline { 2 - 4 } & Visual & Auditori & Kinestetik & \\
\hline Rata-rata & 16,76 & 17,84 & 19,41 & 18,00 \\
Standar deviasi & 2,191 & 3,005 & 2,813 & 1,333 \\
Frekuensi & 10 & 10 & 8 & 1,0 \\
Maximum & 22 & 24 & 25 & 19,41 \\
Minimum & 10 & 10 & 12 & 16,76 \\
\hline
\end{tabular}




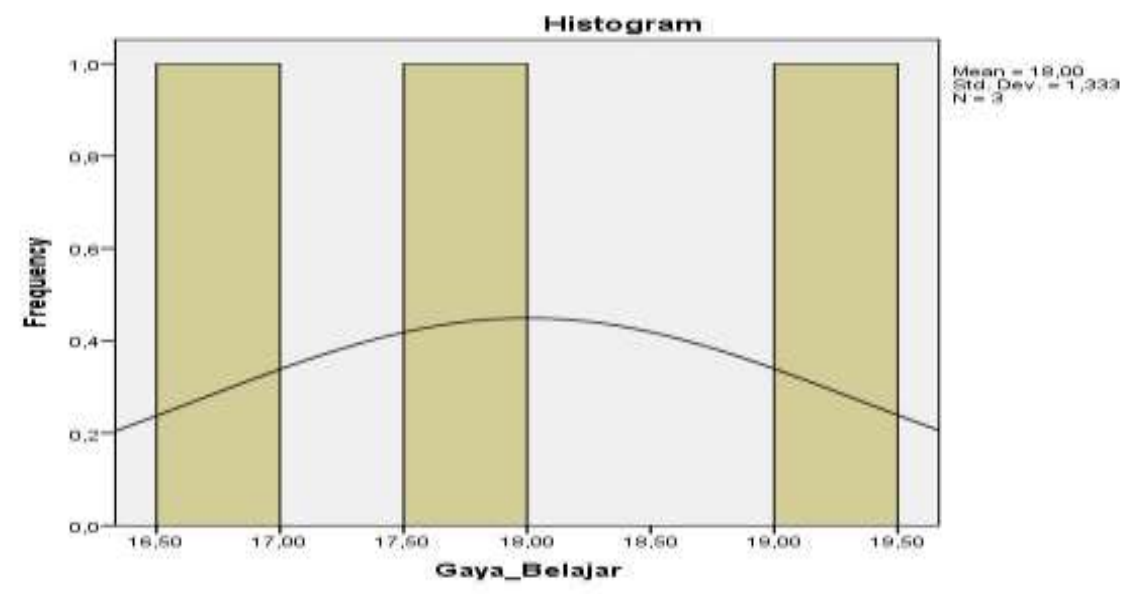

Gambar 1. Histogram Gaya Belajar Mahasiswa

b. Gaya Mengajar

Tabel 6. Tabel Gaya Mengajar Elementary

\begin{tabular}{lccccccccc}
\hline \multirow{2}{*}{ Deskriptif } & \multicolumn{10}{c}{ Elementary } & \multicolumn{1}{c}{ Jumlah } \\
\cline { 2 - 10 } & $\mathbf{1}$ & $\mathbf{2}$ & $\mathbf{3}$ & $\mathbf{4}$ & $\mathbf{5}$ & $\mathbf{6}$ & $\mathbf{7}$ & $\mathbf{8}$ & \\
\hline Rata-rata & 40,73 & 34,44 & 39,00 & 33,00 & 32,45 & 42,75 & 32,24 & 34,48 & 36,14 \\
Standar & 4,987 & 8,292 & 6,329 & 6,306 & 6,983 & 4,499 & 6,224 & 5,984 & 4,093 \\
Deviasi & & & & & & & & & \\
Frekuensi & 10 & 12 & 8 & 6 & 10 & 6 & 6 & 8 & 3 \\
Maximum & 50 & 48 & 50 & 48 & 47 & 50 & 50 & 48 & 42,75 \\
Minimum & 31 & 12 & 20 & 22 & 16 & 31 & 19 & 22 & 32,24 \\
\hline
\end{tabular}

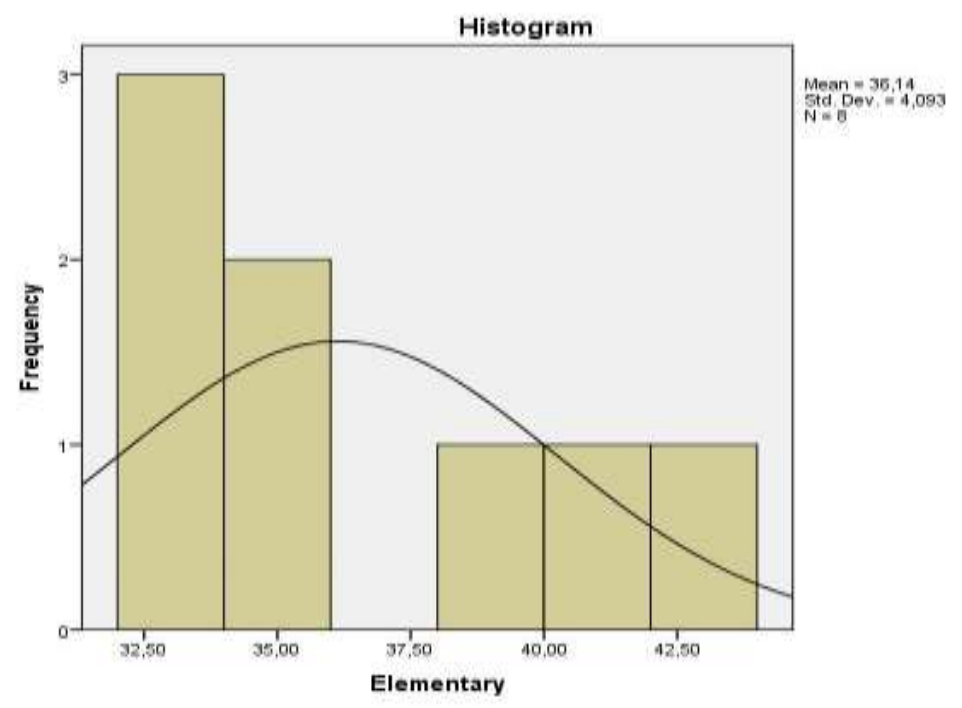

Gambar 2. Histogram Gaya Mengajar Elementary 
Tabel 7. Tabel Gaya Mengajar Intermediate

\begin{tabular}{lccccccccc}
\hline \multirow{2}{*}{ Deskriptif } & \multicolumn{8}{c}{ Intermediate } & \multirow{2}{*}{ Jumlah } \\
\cline { 2 - 8 } & $\mathbf{1}$ & $\mathbf{2}$ & $\mathbf{3}$ & $\mathbf{4}$ & $\mathbf{5}$ & $\mathbf{6}$ & $\mathbf{7}$ & $\mathbf{8}$ & \\
\hline Rata-rata & 26,19 & 34,4 & 25,91 & 21,54 & 22,08 & 23,03 & 22,29 & 23,54 & 24,87 \\
Standar & 4,326 & 3,87 & 4,90 & 4,764 & 3,796 & 4,462 & 4,389 & 4,450 & 4,214 \\
Deviasi & & 2 & & & & & & & \\
Frekuensi & 4 & 5 & 12 & 5 & 6 & 10 & 10 & 12 & 3 \\
Maximum & 34 & 34 & 33 & 30 & 29 & 32 & 37 & 31 & 34,40 \\
Minimum & 18 & 19 & 11 & 14 & 13 & 15 & 11 & 13 & 21,54 \\
\hline
\end{tabular}

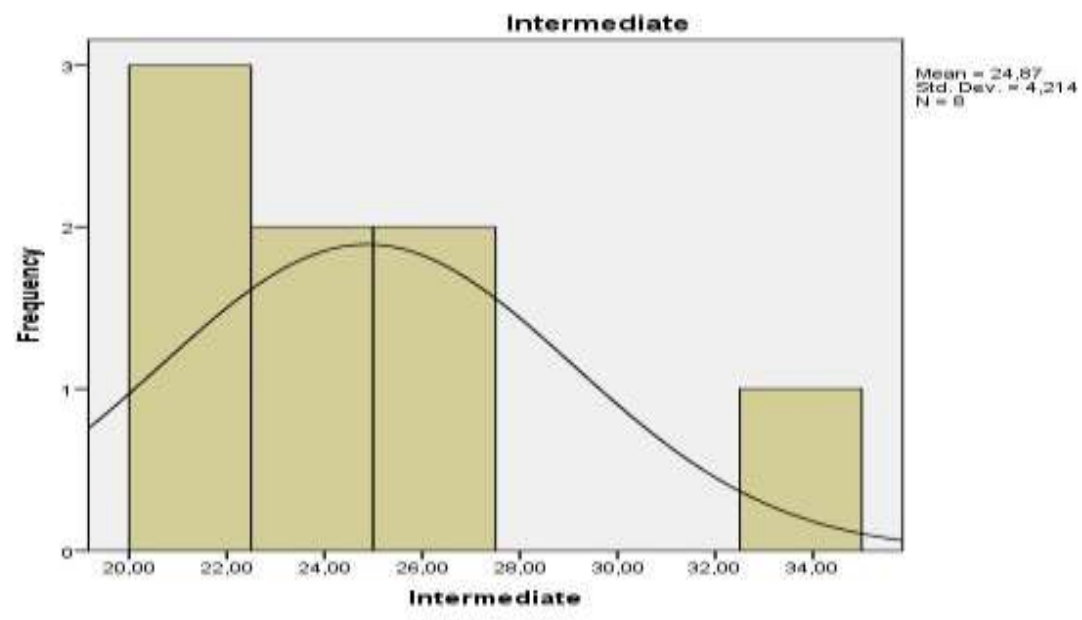

Gambar 3. Histogram Gaya Mengajar Intermediate

Tabel 8. Tabel Gaya Mengajar Advanced

\begin{tabular}{lccccccccc}
\hline \multirow{2}{*}{ Deskriptif } & \multicolumn{10}{c}{ Advanced } \\
\cline { 2 - 8 } & $\mathbf{1}$ & $\mathbf{2}$ & $\mathbf{3}$ & $\mathbf{4}$ & $\mathbf{5}$ & $\mathbf{6}$ & $\mathbf{7}$ & $\mathbf{8}$ & Jumlah \\
\hline Rata-rata & 26,92 & 27,94 & 29,27 & 22,73 & 22,27 & 23,40 & 22,70 & 27,21 & 25,31 \\
Standar & 3,975 & 4,863 & 4,589 & 4,214 & 4,869 & 4,166 & 4,937 & 5,593 & 2,807 \\
deviasi & & & & & & & & & \\
Frekuensi & 6 & 6 & 10 & 8 & 6 & 10 & 8 & 6 & 4 \\
Maximum & 33 & 39 & 37 & 34 & 35 & 32 & 33 & 37 & 29,27 \\
Minimum & 18 & 20 & 18 & 15 & 13 & 12 & 13 & 17 & 22,27 \\
\hline
\end{tabular}




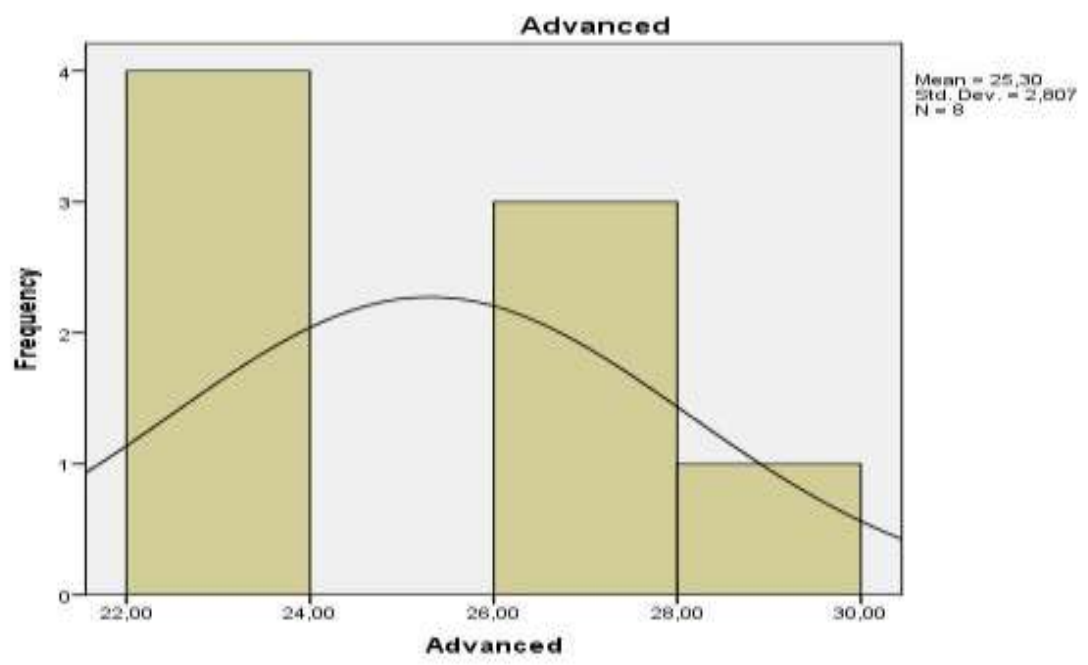

Gambar 4. Histogram Gaya Mengajar Advanced

Tabel 9. Tabel Gaya Mengajar Creative Evaluative

\begin{tabular}{lccccccccc}
\hline \multirow{2}{*}{ Deskriptif } & \multicolumn{8}{c}{ Creative Evaluative } & \multirow{2}{*}{ Jumlah } \\
\cline { 2 - 9 } & $\mathbf{1}$ & $\mathbf{2}$ & $\mathbf{3}$ & $\mathbf{4}$ & $\mathbf{5}$ & $\mathbf{6}$ & $\mathbf{7}$ & $\mathbf{8}$ & \\
\hline Rata-rata & 53,92 & 32,58 & 35,80 & 27,16 & 24,21 & 24,75 & 23,00 & 33,83 & 31,91 \\
Standar & 10,78 & 6,767 & 6,337 & 7,361 & 6,696 & 6,277 & 6,446 & 6,580 & 10,12 \\
deviasi & & & & & & & & & \\
Frekuensi & 8 & 6 & 6 & 6 & 6 & 5 & 6 & 8 & 4 \\
Maximum & 74 & 46 & 47 & 43 & 37 & 36 & 44 & 47 & 53,92 \\
Minimum & 34 & 21 & 23 & 10 & 11 & 11 & 13 & 22 & 23,00 \\
\hline
\end{tabular}

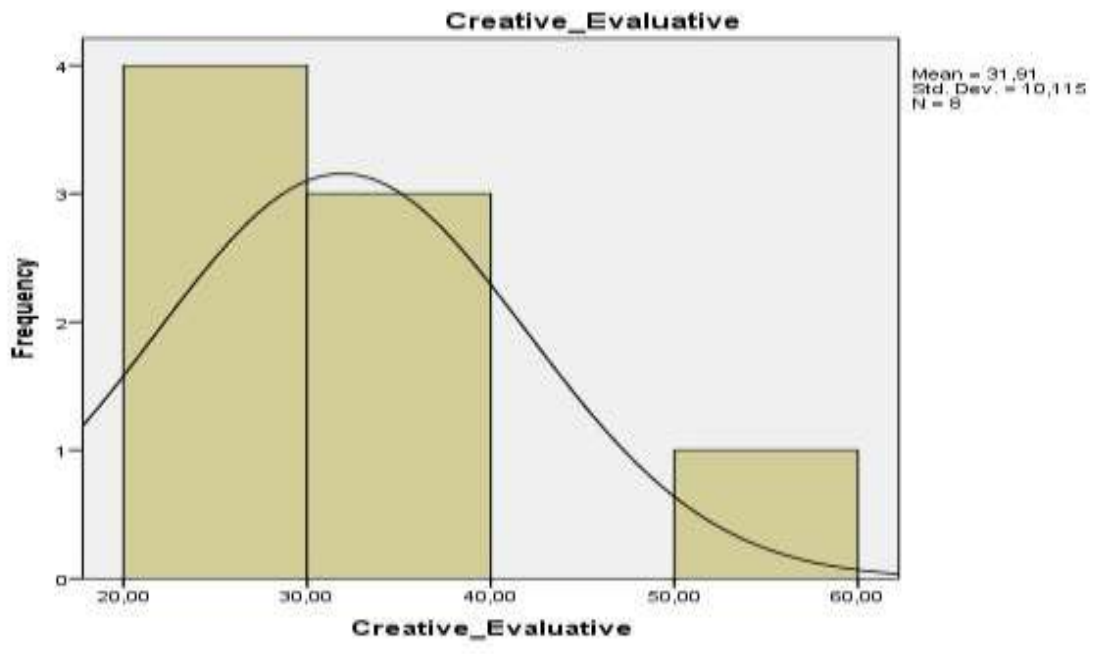

Gambar 5. Histogram gaya mengajar creative evaluative

38 | Volume 5, Nomor 1, Juni 2017 


\section{Uji Prasyarat}

a. Uji Normalitas

Tabel 10. Uji Normalitas Gaya Belajar, Gaya Mengajar, dan Hasil Belajar

\begin{tabular}{|ll|r|r|r|}
\hline \multicolumn{1}{|c|}{ One-Sample Kolmogorov-Smirnov Test } \\
\hline N & & \multicolumn{1}{|c|}{ GM } & \multicolumn{1}{c|}{ GB } & \multicolumn{1}{c|}{ PB } \\
Normal Parameters a.b & Mean & 37 & 37 & 37 \\
& Std. Deviation & 538,05 & 54,00 & 608,65 \\
Most Extreme Differences & Absolute &, 732 & 5,735 & 13,573 \\
& Positive &, 086 &, 149 &, 197 \\
& Negative &,- 086 &, 138 &, 197 \\
Kolmogorov-Smirnov Z & &, 522 &,- 149 &,- 154 \\
Asymp. Sig. (2-tailed) & &, 948 &, 384 & 1,201 \\
\hline
\end{tabular}
a. Test distribution is Normal.

b. Calculated from data.

Keterangan: Data Normal

b. Uji Linearitas

Tabel 11. Uji Linearitas Gaya Belajar, Gaya Mengajar, dan Hasil Belajar

\begin{tabular}{|c|c|c|c|c|c|c|c|}
\hline \multicolumn{8}{|c|}{ ANOVA Table } \\
\hline & & & $\begin{array}{l}\text { Sum of } \\
\text { Squares }\end{array}$ & df & Mean square & $\mathrm{F}$ & sig. \\
\hline \multirow[t]{5}{*}{$G M * P B$} & Between Groups & (Combined) & 14095,389 & 5 & 2349,232 & .666 & .678 \\
\hline & & Linearity & 1746,722 & 1 & 1745,722 & 496 & 487 \\
\hline & & Deviation from Linearity & 12349,667 & 5 & 2469,933 &, 700 & .628 \\
\hline & Within Groups & & 105892,502 & 30 & 3629,750 & & \\
\hline & Total & & 119987,892 & 36 & & & \\
\hline \multirow[t]{5}{*}{$Q B * P B$} & Between Groups & (Combined) & 267,426 & 6 & 44,571 & 1,459 & .226 \\
\hline & & Linearity & 7,976 & 1 & 7,976 & .261 & .613 \\
\hline & & Deviation from Linearity & 259,450 & 5 & 51,890 & 1.698 & .165 \\
\hline & Within Groups & & 916,574 & 30 & 30,562 & & \\
\hline & Total & & 1184.000 & 36 & & & \\
\hline
\end{tabular}

c. Uji Heteroskedasitas

Tabel 12. Uji Heteroskedasitas Gaya Belajar, Gaya Mengajar

Coefficients $^{a}$

\begin{tabular}{|c|c|c|c|c|c|c|}
\hline \multirow{2}{*}{\multicolumn{2}{|c|}{ Model }} & \multicolumn{2}{|c|}{ Unstandardized Coefficients } & \multirow{2}{*}{$\begin{array}{c}\text { Standardized } \\
\text { Coefficients } \\
\text { Beta }\end{array}$} & \multirow[b]{2}{*}{$\mathrm{t}$} & \multirow[b]{2}{*}{ Sig. } \\
\hline & & $\mathrm{B}$ & Std. Error & & & \\
\hline \multirow[t]{3}{*}{1} & (Constant) & 20,470 & 24,350 & & .841 & 406 \\
\hline & GM & .007 & .025 & .049 &, 284 & .778 \\
\hline & GB &,- 309 & .250 & -.212 & $-1,237$ & 225 \\
\hline
\end{tabular}

a. Dependent Variable: RES2

d. Uji multikollinearitas

Tabel 13. Uji Multikollinearitas Gaya Belajar dan Gaya Mengajar

Coefficients $^{a}$

\begin{tabular}{|c|c|c|c|c|c|c|c|c|}
\hline \multirow{2}{*}{\multicolumn{2}{|c|}{ Model }} & \multicolumn{2}{|c|}{ Unstandardized Coefficients } & \multirow{2}{*}{$\begin{array}{c}\begin{array}{c}\text { Standardized } \\
\text { Coefficients }\end{array} \\
\text { Beta }\end{array}$} & \multirow[b]{2}{*}{$t$} & \multirow[b]{2}{*}{ Sig. } & \multicolumn{2}{|c|}{ Collinearity Statistics } \\
\hline & & $B$ & Std. Error & & & & Tolerance & VIF \\
\hline \multirow[t]{3}{*}{1} & (Constant) & 577,225 & 40,126 & & 14,385 &, 000 & & \\
\hline & GM &, 025 &, 041 & .108 &, 622 & .538 & 956 & 1,046 \\
\hline & GB & 140 & .411 & .059 &, 341 & .735 & 956 & 1,046 \\
\hline
\end{tabular}

a. Dependent Variable: PB 


\section{Pengujian Hipotesis}

a. Pengaruh Gaya Belajar $\left(\mathrm{X}_{1}\right)$ Terhadap Hasil Belajar

Tabel. 14. Korelasi Gaya Belajar Terhadap Hasil Belajar

Model Summary ${ }^{b}$

\begin{tabular}{|l|c|c|c|c|}
\hline Model & $R$ & $R$ Square & $\begin{array}{c}\text { Adjusted } R \\
\text { Square }\end{array}$ & $\begin{array}{c}\text { Std. Error of } \\
\text { the Estimate }\end{array}$ \\
\hline 1 & $.082^{a}$ & .007 & -.022 & 13,719 \\
\hline
\end{tabular}

a. Predictors: (Constant), GB

b. Dependent Variable: PB

Tabel 15. Model Regresi Gaya Belajar Terhadap Hasil Belajar

\begin{tabular}{|ll|r|r|r|r|r|}
\hline Model & & $\begin{array}{l}\text { Sum of } \\
\text { Squares }\end{array}$ & df & Mean Square & \multicolumn{1}{c|}{ F } & Sig. \\
\hline 1 & Regression & 44,679 & 1 & 44,679 & .237 & $.629^{\text {b }}$ \\
& Residual & 6587,753 & 35 & 188,222 & & \\
& Total & 6632,432 & 36 & & & \\
\hline
\end{tabular}

a. Dependent Variable: $\mathrm{PB}$

b. Predictors: (Constant), GB

Tabel 16. Model Regresi Gaya Belajar Terhadap Hasil Belajar

Coefficients $^{a}$

\begin{tabular}{|c|c|c|c|c|c|c|}
\hline \multirow[b]{2}{*}{ Model } & & \multicolumn{2}{|c|}{ Unstandardized Coefficients } & \multirow{2}{*}{$\begin{array}{c}\begin{array}{c}\text { Standardized } \\
\text { Coefficients }\end{array} \\
\text { Beta }\end{array}$} & \multirow[b]{2}{*}{$t$} & \multirow[b]{2}{*}{ Sig. } \\
\hline & & $\mathrm{B}$ & Std Error & & & \\
\hline & (Constant) & 598,159 & 21,648 & & 27,631 &, 000 \\
\hline & GB &, 194 & .399 & .082 & 487 & .629 \\
\hline
\end{tabular}

a. Dependent Variable: PB

b. Pengaruh antara Gaya Mengajar $\left(\mathrm{X}_{2}\right)$ Terhadap Hasil Belajar

Tabel 17. Nilai Korelasi Gaya Mengajar Terhadap Hasil Belajar

Model Summary ${ }^{b}$

\begin{tabular}{|l|c|r|r|r|}
\hline Model & $R$ & $R$ Square & $\begin{array}{c}\text { Adjusted } R \\
\text { Square }\end{array}$ & $\begin{array}{c}\text { Std. Error of } \\
\text { the Estimate }\end{array}$ \\
\hline 1 & $.121^{a}$ & .015 & -.014 & 13,665 \\
\hline
\end{tabular}

a. Predictors: (Constant), GM

b. Dependent Variable: PB

Tabel 18. Model Regresi Gaya Mengajar Terhadap Hasil Belajar

ANOVA $^{a}$

\begin{tabular}{|ll|r|r|r|r|c|}
\hline Model & & $\begin{array}{l}\text { Sum of } \\
\text { Squares }\end{array}$ & df & Mean Square & \multicolumn{1}{c|}{ F } & Sig. \\
\hline 1 & Regression & 96,496 & 1 & 96,496 & .517 & $.477^{\text {b }}$ \\
& Residual & 6535,936 & 35 & 186,741 & & \\
& Total & 6632,432 & 36 & & & \\
\hline
\end{tabular}

a. Dependent Variable: PB

b. Predictors: (Constant), GM

40 | Volume 5, Nomor 1, Juni 2017 
Tabel 19. Model Regresi Gaya Belajar Terhadap Hasil Belajar

Coefficients $^{a}$

\begin{tabular}{|c|c|c|c|c|c|c|}
\hline \multirow[b]{2}{*}{ Model } & & \multicolumn{2}{|c|}{ Unstandardized Coefficients } & \multirow{2}{*}{$\begin{array}{c}\begin{array}{c}\text { Standardized } \\
\text { Coefficients }\end{array} \\
\text { Beta } \\
\end{array}$} & \multirow[b]{2}{*}{1} & \multirow[b]{2}{*}{ Sig. } \\
\hline & & $\mathrm{B}$ & Std. Error & & & \\
\hline & (Constant) & 582,047 & 37,075 & & 15,699 &, 000 \\
\hline & GM & ,028 & .039 & .121 & ,719 & .477 \\
\hline
\end{tabular}

a. Dependent Variable: PB

c. Pengaruh Gaya Belajar dan Gaya Mengajar Secara Bersama-Sama Terhadap Hasil Belajar

Tabel 20. Korelasi antara Gaya Belajar dan Gaya Mengajar terhadap Hasil Belajar

\begin{tabular}{|c|c|c|c|c|}
\hline & & $P B$ & GM & $O B$ \\
\hline \multirow{3}{*}{ PEarson Corralation } & $P B$ & 1.000 & $.1>1$ & 087 \\
\hline & $G M$ & .121 & 1,000 & .211 \\
\hline & $\mathrm{OB}$ & .082 &, 211 & 1,000 \\
\hline \multirow[t]{3}{*}{ sig. (1-tailed) } & $P B$ & + & .239 & .315 \\
\hline & OM & .239 & & .105 \\
\hline & $O B$ & .315 & .105 & . \\
\hline \multirow[t]{3}{*}{$\mathrm{N}$} & $P B$ & 37 & 37 & 37 \\
\hline & $G M$ & 37 & 37 & 37 \\
\hline & GB & 37 & 37 & 37 \\
\hline
\end{tabular}

Tabel 21. Model Summary antara Gaya Belajar dan Gaya Mengajar

Model Summary

\begin{tabular}{|l|l|r|r|r|}
\hline Model & $\mathrm{R}$ & $\mathrm{R}$ Square & $\begin{array}{c}\text { Adjusted } \mathrm{R} \\
\text { Square }\end{array}$ & $\begin{array}{c}\text { Std. Error of } \\
\text { the Estimate }\end{array}$ \\
\hline 1 &, $134^{\mathrm{a}}$ &, 018 &,- 040 & 13,841 \\
\hline
\end{tabular}

a. Predictors: (Constant), GB, GM

Tabel 22. Anova antara Gaya Belajar dan Gaya Mengajar terhadap Hasil Belajar

ANOVA $^{\mathrm{a}}$

\begin{tabular}{|ll|r|r|r|r|r|}
\hline Model & & \multicolumn{1}{c}{$\begin{array}{l}\text { Sum of } \\
\text { Squares }\end{array}$} & df & Mean Square & \multicolumn{1}{c|}{ F } & Sig. \\
\hline 1 & Regression & 118,774 & 2 & 59,387 & .310 & $7^{6} 6^{\text {b }}$ \\
& Residual & 6513,658 & 34 & 191,578 & & \\
& Total & 6632,432 & 36 & & & \\
\hline
\end{tabular}

a. Dependent Variable: $\mathrm{PB}$

b. Predictors: (Constant), GB, GM 
Tabel 23. Coefisien antara Gaya Belajar dan Gaya Mengajar terhadap Hasil Belajar

\begin{tabular}{|c|c|c|c|c|c|c|}
\hline \multicolumn{7}{|c|}{ Coefficients $^{a}$} \\
\hline \multirow{2}{*}{\multicolumn{2}{|c|}{ Model }} & \multicolumn{2}{|c|}{ Unstandardized Coefficients } & \multirow{2}{*}{$\begin{array}{c}\text { Standardized } \\
\text { Coefficients } \\
\text { Beta }\end{array}$} & \multirow[b]{2}{*}{$t$} & \multirow[b]{2}{*}{ Sig. } \\
\hline & & $\mathrm{B}$ & Std. Error & & & \\
\hline \multirow[t]{3}{*}{1} & (Constant) & 577,225 & 40,126 & & 14,385 &, 000 \\
\hline & GM &, 025 & .041 & .108 &, 622 & .538 \\
\hline & GB & 140 & .411 & .059 &, 341 & .735 \\
\hline
\end{tabular}

a. Dependent Variable: PB

Berdasarkan hasil analisis data menunjukkan bahwa kontribusi dari gaya mengajar yang berpengaruh terhadap hasil belajar matematika, yaitu: 1)gaya mengajar elementarydosen jurusan pendidikan matematika UIN Alauddin Makassar diperoleh melalui angket tertutup yang terdiri dari 43 butir pernyataan dan terdiri dari 37 responden. Setelah diolah dapat diketahui nilai maksimum dari gaya mengajar elementary sebesar 42,75 dan nilai minimum sebesar 32,24. Berdasarkan hasil pengolahan data diperoleh diperoleh rata-ratasebesar 36,14 dan standar deviasi (SD) sebesar 4,093. 2)gaya mengajar intermediatedosen jurusan pendidikan matematika UIN Alauddin Makassar diperoleh melalui angket tertutup yang terdiri dari 43 butir pernyataan dan terdiri dari 37 responden. Setelah diolah dapat diketahui nilai maksimum dari gaya mengajar intermediate sebesar 34,40 dan nilai minimum sebesar 21,54. Berdasarkan hasil pengolahan data diperoleh diperoleh rata-ratasebesar 24,87 dan standar deviasi (SD) sebesar 4,214. 3)gaya mengajar advanceddosen jurusan pendidikan matematika UIN Alauddin Makassar diperoleh melalui angket tertutup yang terdiri dari 43 butir pernyataan dan terdiri dari 37 responden. Setelah diolah dapat diketahui nilai maksimum dari gaya mengajar advanced sebesar 29,27 dan nilai minimum sebesar 22,27. Berdasarkan hasil pengolahan data diperoleh diperoleh rata-ratasebesar 25,31 dan standar deviasi (SD) sebesar 2,807. 4) gaya mengajar creative evaluativedosen jurusan pendidikan matematika UIN Alauddin Makassar diperoleh melalui angket tertutup yang terdiri dari 43 butir pernyataan dan terdiri dari 37 responden. Setelah diolah dapat diketahui nilai maksimum dari gaya mengajar creative evaluative sebesar 53,92 dan nilai minimum sebesar 23,00. Berdasarkan hasil pengolahan data diperoleh diperoleh rata-ratasebesar 31,91 dan standar deviasi (SD) sebesar 10,12 . Setelah dilakukan pengujian hipotesis, maka dapat di lihat bahwa gaya belajar dan gaya mengajar mahasiswa akan berpengaruh terhadap hasil 
belajar. Selain itu dalam hipotesis dilihat bahwa mahasiswa jurusan pendidikan matematika UIN Alauddin yang dijadikan sampel memiliki gaya belajar kinestetik dan gaya mengajar creative evaluative.

\section{SIMPULAN}

Pengaruh gaya belajar terhadap hasil belajar matematika masih tergolong kecil, hal ini disebabkan hal ini disebabkan karena kadang teori yang diajarkan dikelas mahasiswa kurang paham dan mereka cenderung tidak mau mempelajarinya lagi, selain itu mahasiswa cenderung kurang memahami gaya belajar yang mereka miliki. Pengaruh gaya mengajar terhadap hasil belajar matematika masih cenderung kurang, hal ini disebabkan karena kondisi mahasiswa dan dosen itu sendiri pada proses pembelajaran dan penyampaian materi oleh dosen ke mahasiswa cenderung tidak sampai. Gaya belajar dan gaya mengajar sangat berpengaruh terhadap hasil belajar matematika mahasiswa jurusan pendidikan matematika UIN Alauddin Makassar, walaupun memiliki pengaruh yang kurang berdasarkan hasil data penelitian yang diperoleh.

\section{DAFTAR PUSTAKA}

Arifin , Z. (2009). Evaluasi pembelajaran. Bandung: PT. Remaja Rosdakarya.

Azwar, S. (2000). Reliabilitas dan validitas (edisi III). Cetakan II. Yogyakarta: Pustaka Pelajar.

Azawar, S. (2011). Pengantar psikologi intelegensi Cet III; Yogyakarta: Pustaka Pelajar.

Djamarah, S.B, \& Zein, A. (1997). Atrategi belajar mengajar. Jakarta: PT. Rineka Cipta.

Djamarah, S.B. (2000). Guru dan anak didik dalam interaksi edukatif. Jakarta: PT. Rineka Cipta.

Djamarah, S.B. (2002). Psikologi belajar. Jakarta: PT. Rineka Cipta.

Hasan. I. (2010). Pokok-pokok materi statistik 2 statistik inferensial. Jakarta: Bumi Aksara.

Slameto. (2003). Belajar dan faktor-faktor yang mempengaruhinya. Jakarta: PT. Asmadi Mahasatya. 
Soedjadi, R. (2000). Kiat pendidikan matematika di Indonesia. Jakarta: Departemen Pendidikan Nasional.

Sundari, S. (1992). Dasar-dasar psikologi pendidikan. Yogyakarta: Swadaya.

Suherman. E, Winataputra, \& Udin, S. (1992). Strategi belajar mengajar matematika. Jakarta: Departemen Pendidikan dan Kebudayaan.

Slameto. (2003). Belajar dan faktor-faktor yang mempengaruhinya. Jakarta: PT. Asmadi Mahasatya.

Suryabrata, S. (2005). Metodologi penelitian. Jakarta: PT. Raja Grafindo Persada.

Suryabrata, S. (2008). Psikologi pendidikan. Jakarta: PT Raja Grafindo Persada.

Syah, M. (2010). Psikologi pendidikan dengan pendekatan baru. Bandung: PT. Remaja Rosdakrya Offset.

Tiro, A. M. (2004). Pengenalan biostatistika. Makassar: Andira Publisher.

Uno, Hamzah, B., \& Masri, K. 2009. Mengelola kecerdasan dan pembelajaran sebuah konsepsi pembelajaran berbasis keecerdasan. Jakarta: PT. Bumi Aksara. 